\title{
Dis-Placed: Space, Settlement, and Agency
}

\begin{abstract}
This article introduces the special issue 'Dis-placed'. Questioning the term 'refugee' as an identity marker and pointing at the problematic connotations it embodies, the article explores the spatial forms of refugee experience. The knowledge of space, as produced within disciplines such as geography, urban planning, and architecture, is deployed by states to limit the movements of forced migrants across and within national borders. In response, the article calls for social/spatial justice, arguing that this can only be achieved through the blurring of the boundaries between host and refugee identities. The contributions in this special issue present investigations on different facets of the spatiality of forced migration through various disciplinary approaches and methodologies. Taken together, they underline the importance of the link between space and refugee agency in tackling forced migration.
\end{abstract}

According to the United Nations High Commissioner for Refugees (UNHCR), at least 100 million individuals were forcibly displaced by conflict, economic hardship and other factors between 2010 and 2019. Only a fraction of the displaced found a solution in the form of settlement; the number of displaced persons was around 80 million by the end of 2019, the highest it had been since the end of the Second World War. ${ }^{1}$ Such figures clearly show the persistence of forced displacement as a political problem and the failure of the international authorities to find a solution to the protracted suffering of refugees. ${ }^{2}$

\section{Keywords}

refugee displacement forced migration refugee agency refugee camp mobility 
The topic of dis-placement and the dis-placed has been hotly debated by policy makers as well as scholars of various disciplines. This special issue focuses on the spatial forms and urban consequences of forced migration, which fall within the purview of IJIA in two respects: the geographies of refugee mobility and their major overlap with the transnational geography of Islam around the globe; and attention to design and the objective to develop dialogue between practitioners and scholars. Many refugee groups displaced in recent years are Muslim (or are presumed to be) and in some cases have been met with Islamophobic hostility. The ethical dimension of forced migration has led practitioners to develop proposals for alternatives to refugee camps with the result that the interaction between these works and the critical scholarship on forced migration is vital for the further advancement of both perspectives. ${ }^{3}$

It is crucial to investigate the spaces and the spatiality of forced migration alongside that of migrant agency. Failure to do so leads to the acceptance of the term 'refugee' as an identity marker without addressing the problematic connotations it embodies. Refugee identity at once essentializes and contributes to the othering of those labeled as such, as well as falsely homogenizing the dislocated individuals and groups. ${ }^{4}$ The perception of forced migration as a crisis reflects more than simply a humanitarian call, as it is a response that manifests in the fortification of the borders of states, particularly in the Global North. ${ }^{5}$ The popular term 'refugee crisis' presents the refugee as a problem in the form of an objectified person who is denied active agency and subjected to incarceration in various spaces of exception, which range from incarceration sites to refugee camps. The 'free' existence of refugees in the contemporary metropolis is marked by precarity, a quality that has become a characteristic feature of the neoliberal urban milieu.

Considered in this light, the refugee does indeed represent a crisis, in part by problematizing the status quo within and across borders that are established on the primacy of the nation-state and its regimes of governance. This problematization thus includes the very definition of citizenship. Within this framework, knowledge of space, as produced within disciplines such as geography, urban planning, and architecture, is deployed to limit the movements of forced migrants across and within national borders. In response, critical scholarship scrutinizes the sites, practices, and processes of refugee governance. Emergent terms such as 'hospitality', 'alien', 'host', 'stranger', and 'destination' assume new meanings as indexes of the precarious status of the refugee.

It is not only the status but also the spaces and movements of the refugee that exhibit precarity. The spatiality of forced migration presents a vast field of inquiry, as it is possible to identify various spatial forms of refugee experience. The first spatial form is comprised of the spaces of mobility, since the movement of migrants across borders occurs through particular routes displaying particular forms of spatiality. The 'Balkan Route' used by Syrian, African, and Afghan migrants heading toward western Europe, and the 'migrant caravans' of Central America not only transgress national borders but also produce new territorialities. ${ }^{6}$ In this sense, deserts and seas have become territories of contestation and extra-national fields of survival, oblivion, and exception. ${ }^{7}$ The consideration of migrant and refugee routes as spaces calls for scholars to take seriously the notion of 'mobility justice', which is based on the idea that social inclusion and exclusion are constituted through (im)mobilities. ${ }^{8}$

The second spatial form is that of state-controlled incarceration, including asylum, detention, and deportation centres, transit camps, prisons, and 
ghettos. The biopolitics of nationless bodies has a spatial character that is based on organized immobility. Moreover, such spaces have the potential to remake borders, albeit away from the territorial edges of nation states; it is crucial to note that, in doing so, they become a means of spatial order, and therefore terrains of political struggle. ${ }^{9}$

The third spatial form is the refugee camp, which simultaneously reflects practices of refugee governance as well as refugee agency in the production of the camp as social space..$^{10}$ These nomadic spaces curiously have much in common with utopian urbanisms of the post-Second-World-War architectural avant-garde. Thus, even in their precarious conditions, camps have inspired artists and architects to imagine alternate spatialities. ${ }^{11}$ It is also worth considering the non-urban character of camps, which is the result of the unwillingness of the 'host' states to integrate refugees into their urban networks and a preference instead to locate them in undeveloped border areas. ${ }^{12}$ The refugee camps, especially the larger and longer-standing ones, do act as cities, but they make it necessary to distinguish between urban and city: although the prolonged existence of larger camps turns them into city-like settlements, they deny their inhabitants the political rights and benefits of urban life..$^{13}$ Either way, the refugee camps present socially as well as physically marginal conditions, on national as well as transnational scales. States engage in both open and covert cooperation in their governance of refugee mobility. This is seen in the striking case of the so-called 'PNG solution' between Australia and Papua New Guinea, in which the former has built detention facilities within the latter's territory. ${ }^{14}$

The fourth spatial form is the new urban condition under the multi-dimensional effects of forced migration in what is otherwise known as the city. ${ }^{15}$ The displaced subjectivity of refugees, who frequently 'blend in' as a hidden population within urban spaces, should be considered as a symptom of the segregation, discrimination, and general inequality inherent in the contemporary metropolis. Here, it is also crucial to consider the historical circumstances that triggered the current wave of forced migration. Recent episodes of war and destruction are closely related to the crisis of neoliberalism, the effects of which include the destruction of public space, gentrification, the emergence of gated communities, and increases in inequality in the urban sphere. These predicaments of neoliberalization led to the global wave of mass protests that took place between 2011 and 2013. ${ }^{16}$ These protests were often responses to economic impoverishment and took the form of the Occupy movements in the Global North and the 'Arab Spring' as it was called by observers of the dynamics in the Middle East and North Africa. In broad terms, these were globally connected and mutually inspired revolts against commodification and authoritarianism. ${ }^{17}$ There is a curious link between the figure of the refugee and the urban focus of these protests. The refugee represents a generalized condition of the urban politics that marked the protests. The refugee-as-nomad seeks and produces new spatialities_ambiguous architectures of precarity-and in this respect opens room for the consideration of alternative urban experiences and the possibility of reimagining the city as a commons. ${ }^{18}$

\section{This Special Issue}

'Dis-placed' was chosen as the theme for this issue in order to underline the dialectics of refugee existence. The refugee is, by definition, displaced, but refugees are also placed in two senses. They find a place to settle but are also 
subject to the resettlement project of power. Therefore, the articles presented in this issue explore the themes of spatiality, settlement, and agency in an attempt to uncover the multiplicity of actors in shaping refugee presence.

The first two articles present historical cases. The first, by Timur Saitov, discusses the refugees of the Russian Civil War (1918-20) who arrived in Istanbul, the capital of the Ottoman Empire, at that time under Allied occupation in the wake of the First World War. Interestingly, the Allied forces' attempts at controlling the occupied city overlapped with the need to organize the Russian migrants; hence, the marginalization of the Russian refugees was militarized from the beginning. Some were placed in camps designed for refugees in and around Istanbul. Those who found their way into the city could not escape the control mechanisms of occupation, either. As Saitov shows, the experience of the Russian refugees in Istanbul was caught up within the power struggle between the Allied powers, the Ottoman Empire, and newlyborn Soviet Russia, thereby becoming an important episode in the making of the modern international refugee regime.

The second historical case, discussed by Nadi Abusaada, focuses on the operations of the Arab Development Society (ADS) in Palestine from 1945 to 1955. Initially a rural development project promoting village modernization, after 1948, the ADS turned into an instrument of housing for the Palestinian refugees in the Jordan Valley. Seeking to develop an autonomous Palestinian vision for refugee resettlement, the ADS challenged foreign experts and their views and demonstrated that a Palestinian self-help effort was possible. Although the ADS failed to accomplish its objectives for a number of reasons, Abusaada argues that the key issue was the 'authoritarianism' of the modernist Arab experts themselves, which alienated and denied agency to the refugees. These two historical articles exemplify early attempts to control and regulate refugee mobility, but more importantly, they demonstrate the persistent denial of agency for refugees, regardless of the hostility or empathy exhibited by the authorities.

The next two articles present spatial perspectives on the contemporary situation of Syrian refugees, the first from an urban planning perspective and the second from an architectural standpoint. Feriha Nazda Güngördü and Zerrin Ezgi Kahraman investigate the factors that determine urban refugees' settlement site selections, known in the literature as location choices (LC). Based on fieldwork interviews conducted in Turkey in the Önder neighbourhood of the capital city of Ankara and the Yunusemre neighbourhood of İzmir on the Aegean coast, the article presents a comparative analysis of the dynamics of location choices of Syrian refugees. Both neighbourhoods, situated close to inner-city industrial sites, display common context-dependent socioeconomic, socio-cultural, and socio-spatial themes. Yet, they also embody different characteristics, particularly in relation to the ethnic compositions of the neighbourhoods. While Ankara's Önder has turned into an ethnic enclave with a predominantly Syrian population, İzmir's Yunusemre has attracted Sunni Syrian refugees who now live alongside a resident Kurdish community and a pre-existing population of devout Turkish Muslims. The findings of the article regarding the factors of location choices for refugees are presented with the intention of providing insights for policy makers.

Howayda Al-Harithy, Abir Eltayeb, and Ali Khodr investigate the housing conditions of Syrian refugees in Saida, Lebanon, using the perspective of spatial justice. Despite Saida's historical identity as a host city for refugees without spatial segregation and containment, the country's current 'no camp' 
policy and the government's denial of refugee status to the Syrians fleeing civil war have forced the displaced refugees into rental apartments or collective shelters with substandard and deteriorating conditions. The study shows that, in both cases, the refugees face stigmatization and marginalization, and housing provision turns into a mechanism of social exclusion. The authors call for the recognition of the refugees as active agents of urban transformation as an expression of spatial justice.

The last two articles explore the subjective spatial experiences of refugees, particularly refugee minors, and offer a view of displaced children as resilient people with a capacity to appropriate and adapt their environments. Valentina Fedele and Anna Elia discuss the case of unaccompanied minors hosted in reception centres in Calabria, Italy. Investigating the daily lives of minors in this space of exception via interviews, the authors emphasize the role played by religion, in this case Islam, in the making and maintenance of the children's subjectivities. The study shows how religion functions as a reference for identification and serves as a structure of meaning. Moreover, as the article demonstrates, religion is not only a discursive reference of moral orientation but a material factor regulating the spatial practices of daily life and the spatial making of refugee minors' subjectivities.

In the last article of the issue, Roula El Khoury and Paola Ardizzola focus on refugee children's appropriation of the spaces they inhabit. Through a comparative analysis of the informal play areas of children in inner-city neighbourhoods of Beirut and the Burj Al-Barajneh refugee camp at the outskirts of the city, the authors scrutinize the children's cognitive relationship to space. Whether within the inner-city urban voids or the informal setting of the camp, the children display a significant capacity to re-imagine, re-semanticize, and appropriate space. Through this imaginative and playful occupation of space, the children overcome some aspects of the trauma caused by their displacement and produce spaces that are their own in a camp and a city that constantly alienate them as refugees.

The contributions in this special issue present investigations on different facets of the spatiality of forced migration through various disciplinary approaches and methodologies. The historical analyses shed light on the earliest attempts at settling refugees, and the spatial investigations present analysis on different scales that offer insights for policy making. The last two articles bring in a phenomenological approach and investigate the interrelationship of space and refugee subjectivity. While each article focuses on the agency of a different actor (states, experts, refugee families, children) social and spatial justice emerge as common aims in calling for the animation of refugee agency.

Taken together, this collection underlines the importance of the link between space and refugee agency in tackling forced migration. It is necessary to see the refugees as spatial agents, i.e., as (political) agents making and remaking the spaces they inhabit and all the environments they interact with. This means acknowledging the transformative impact the displaced have on spatial forms of social organization, including neighbourhoods, cities, and even national territories. In this sense, social and spatial justice can only be achieved through the blurring of the boundaries between host and refugee identities, as conceived with reference to nationality. It is true that the near future does not hold promise in this regard, given the rise of racism, xenophobia and Islamophobia under the wings of right-wing populism. Yet, there is still reason for optimism, considering the persistence of pro-refugee activism and its inspirational influence within the field of architecture. 


\section{Acknowledgements}

I am grateful to Mohammad Gharipour and Kıvanç Kılınç for inviting me to edit this volume and for their insightful comments on the initial idea of the special issue. I would also like to thank Eliana Abu-Hamdi, who worked with me on the issue as in-house editor. Finally, I would like to thank the contributors for their dedicated work and committed scholarship.

\section{Suggested Citation}

Batuman, Bülent (2021), 'Dis-Placed: Space, Settlement, and Agency', International Journal of Islamic Architecture, 10:2, pp. 327-334, doi: https://doi. org/10.1386/ijia_00046_1

\section{Contributor Details}

Bülent Batuman is an associate professor of architecture at Bilkent University with joint appointment at the Department of Urban Design and Landscape Architecture and the Department of Architecture. He studied at the Middle East Technical University and received his Ph.D. in History and Theory of Art and Architecture from State University of New York-Binghamton. His research areas include social production and politics of built environment, history and theory of modern architecture and urbanism, and urban politics. His recent work focuses on the relationship between Islamism and the built environment. He is the author of New Islamist Architecture and Urbanism: Negotiating Nation and Islam through Built Environment in Turkey (Routledge, 2018) and editor of Cities and Islamisms: On the Politics and Production of the Built Environment (Routledge, 2021).

Contact: Bilkent University Faculty of Art, Design and Architecture, 06800 Cankaya, Ankara, Turkey.

Email: batuman@bilkent.edu.tr

Bülent Batuman has asserted their right under the Copyright, Designs and Patents Act, 1988, to be identified as the author of this work in the format that was submitted to Intellect Ltd.

\section{Endnotes}

1. United Nations High Commissioner for Refugees (UNHCR), Global Trends: Forced Displacement in 2019 (Geneva: UNHCR, 2020), 4.

2. The latest international attempt was comprised of the non-binding Global Compact on Refugees (GCR) and the Global Compact for Safe, Orderly and Regular Migration (GCM), both of which were adopted by the UN General Assembly in December of 2018. For a discussion of the two compacts and the gaps they contain, see Elizabeth E. Ferris and Susan F. Martin, 'The Global Compacts on Refugees and for Safe, Orderly and Regular Migration: Introduction to the Special Issue', International Migration 57.6 (2019): 5-18.

3. There are Non-Governmental Organizations such as Architecture Sans Frontières International as well as numerous platforms conducting architectural research and building shelters for refugees. For an example 
see Architecture for Refugees, accessed January 12, 2021, http:// architectureforrefugees.com. There are individual practices such as Estudio Teddy Cruz + Fonna Forman whose recent work tackles the US-Mexican border question. Teddy Cruz and Fonna Forman, 'Unwalling Citizenship', e-flux Architecture, November 3, 2020, https://www.e-flux.com/architecture/ at-the-border/358908/unwalling-citizenship/. There are also newly established practices seeking architectural proposals especially in Europe. For examples, see the Maidan Tent proposed as a social hub (initially for a refugee camp in Ritsona, Greece) by Bonaventura Visconti di Modrone and Leo Bettini Oberkalmsteiner, accessed January 12, 2021, https://www. maidantent.org/; and the Cortex Shelter, by Cutwork Studio, accessed January 12, 2021, https://cutworkstudio.com/cortex-shelter. It is worth noting that furniture retailer IKEA won the Design Museum's 2016 Design of the Year award with its 'Better Shelter'. See Patrick Lynch,'IKEA's Better Shelter Wins Design of the Year 2016', ArchDaily, January 27, 2017, https://www. archdaily.com/804247/ikeas-better-shelter-wins-design-of-the-year-2016.

4. See for example the recent special issue of Refuge on 'Intersectional Feminist Interventions in the "Refugee Crisis"'; Anna Carastathis, Natalie Kouri-Towe, Gada Mahrouse, and Leila Whitley, 'Introduction', Refuge 34.1 (2018): 3-15. For racial and religious othering of refugees in Europe, see Piro Rexhepi, 'Arab Others at European Borders: Racializing Religion and Refugees Along the Balkan Route', Ethnic and Racial Studies 41.12 (2018): 2215-34.

5. Jennifer Hyndman and Johanna Reynolds, 'Beyond the Global Compacts: Re-imagining Protection', Refuge 36.1 (2020): 66-74.

6. Barbara Beznec, Marc Speer, and Marta M. Stojić Mitrović, Governing the Balkan Route: Macedonia, Serbia and the European Border Regime (Belgrade: Rosa Luxemburg Stiftung Southeast Europe, 2016); Noelle K. Brigden, 'A Visible Geography of Invisible Journeys: Central American Migration and the Politics of Survival', International Journal of Migration and Border Studies 4.1-2 (2018): 71-88.

7. Vicki Squire, 'Governing Migration through Death in Europe and the US: Identification, Burial and the Crisis of Modern Humanism', European Journal of International Relations 23.3 (2017): 513-32.

8. Mimi Sheller, Mobility Justice: The Politics of Movement in an Age of Extremes (New York: Verso, 2018), 1.

9. Melanie Hartmann, 'Contested Boundaries: Refugee Centers as Spaces of the Political', Z'Flucht 1.2 (2017): 218-43.

10. The refugee camp as a space of exception has been scrutinized in the fields of political science as well as geography: Bülent Diken and Carsten Bagge Laustsen, The Culture of Exception: Sociology Facing the Camp (London: Routledge, 2005); Adam Ramadan, 'Spatialising the Refugee Camp', Transactions of the Institute of British Geographers 38.1 (2013): 65-77; Lucas Oesch, "The Refugee Camp as a Space of Multiple Ambiguities and Subjectivities', Political Geography 60 (2017): 110-20. 
11. See Alessandro Petti, Sandi Hilal, and Eyal Weizman, Architecture after Revolution (Berlin: Sternberg Press, 2013); Pelin Tan and Ömer Faruk Günenç, 'Camp: Decolonizing Architecture', in Architecture in Emergency: Re-Thinking the Refugee Crisis, ed. Neslihan Dostoğlu, Evren Burak Enginöz, Serhat Kut, and Erhan Karakoç (Istanbul: Istanbul Kültür University, 2017), 20-23.

12. Marc-Antoine Perouse de Montclos, 'Refugee Camps or Cities? The Socioeconomic Dynamics of the Dadaab and Kakuma Camps in Northern Kenya', Journal of Refugee Studies 13.2 (2000): 205-22. Manuel Herz, From Camp to City: Refugee Camps of the Western Sahara (Zurich: Lars Muller Publishers, 2012).

13. Neil Brenner and Christian Schmid, "Towards a New Epistemology of the Urban?', City 19.2-3 (2015): 151-82. For a discussion of the refugee camp in relation to city as political unit, see Peter Grbac, 'Civitas, Polis, and Urbs: Reimagining the Refugee Camp as the City', Refugee Studies Centre Working Paper Series 96 (Oxford: Refugee Studies Centre, Oxford Department of International Development, University of Oxford, 2013).

14. Human Rights Watch and Human Rights Law Centre, 'The Pacific NonSolution: Two Years On, Refugees Face Uncertainty, Restrictions on Rights', HRLC.org, July 16, 2015, https://www.hrlc.org.au/news/the-pacific-nonsolution-two-years-on-refugees-face-uncertainty-restrictions-onrights?rq=pacific\%20non-solution.

15. Ananya Roy, 'Slumdog Cities: Rethinking Subaltern Urbanism', International Journal of Urban and Regional Research 35 (2011): 223-28; Jonathan Darling, 'Forced Migration and the City: Irregularity, Informality, and the Politics of Presence', Progress in Human Geography 41.2 (2017): 178-98; Mona Fawaz, Ahmad Gharbieh, Mona Harb, and Dounia Salame, eds, Refugees as CityMakers (Beirut: American University of Beirut, 2018).

16. David Harvey, Rebel Cities: From the Right to the City to the Urban Revolution (New York: Verso, 2012), 115-64.

17. Andy Merrifield, The Politics of the Encounter: Urban Theory and Protest under Planetary Urbanization (Athens: University of Georgia Press, 2013).

18. Cathrine Brun and Anita Fábos, 'Making Homes in Limbo? A Conceptual Framework', Refuge 31.1 (2015): 5-17. For the city as commons, see Stavros Stavrides, Common Space: The City as Commons (London: Zed Books, 2016). 